UDC: $371.13: 37.037$

DOI: https://doi.org/10.24195/2414-4665-2017-5-16

\author{
Viktoriia Nesterenko, \\ Doctor of Pedagogy, professor, Department of Preschool Pedagogy, \\ South Ukrainian National Pedagogical University named after K. D. Ushynsky, \\ 1, Nishchinskoho Str., Odesa, Ukraine,
}

Hanna Titova,

PhD (Candidate of Pedagogical Sciences), senior lecturer, Department of Athletic Games, South Ukrainian National Pedagogical University named after K. D. Ushynsky,

4, Fontanska Doroha Str., Odesa, Ukraine

\title{
THE CONTENT OF PREPARING FUTURE PHYSICAL EDUCATION TEACHERS FOR FORMING LEADERSHIP QUALITIES IN MIDDLE SCHOOL STUDENTS
}

The paper presents the content of preparing future Physical Education teachers for the formation of sportsoriented leadership qualities in middle school students according to the following pedagogical conditions: reflecting the ideas about the essence and mechanisms of leadership formation in the content of preparing future PE teachers; mastering the technique of pedagogical support of the formation of students' sports-oriented leadership qualities at PE classes; getting future PE teachers involved in situations requiring the formation of students' sports-oriented leadership qualities in team and playing sports. According to the first pedagogical condition, the content of the programme for the subject "Theory and Methods of Teaching Athletic Games" was supplemented with the following topics: leadership qualities and characteristic features of their demonstration; factors of forming sports-oriented leadership qualities; peculiarities of sports-oriented leadership qualities demonstration by middle school students in team and playing sports, etc. Mastering the technique of pedagogical support of the formation of sports-oriented leadership qualities in school students (the second pedagogical condition) was implemented by means of various training and educational events, namely: problem-based and discussion-based lectures, business games, roleplaying games, trainings, etc. The third pedagogical condition presupposed systematisation of knowledge acquired by students and development of firm activity stereotypes related to the formation of middle school students' sports-oriented leadership qualities in team and playing sports. For this purpose, athletic games classes involved exercising organisation of middle school students' activities aimed at the formation of sports-oriented leadership qualities in team games. Results of the experimental data analysis confirmed the effectiveness of the proposed pedagogical conditions, which have been implemented in the process of preparing future PE teachers for forming middle school students' sports-oriented leadership qualities.

Keywords: training, future teachers of Physical Education, pedagogical conditions, sports-oriented leadership qualities, middle school students.

\section{Introduction}

The issue of training ambitious adolescents, who are able to be leaders due to corresponding qualities, abilities and skills, and be responsible for making important decisions in future, is one of the important task of contemporary school education.

Thesis works of Ukrainian researchers are devoted to various aspects of leadership: education of personality's leadership qualities in contemporary comprehensive schools (D. Alfimov), in senior school pupils in the activities of pupils' government (O. Kosenchuk), in future teachers in the system of student government ( $\mathrm{Yu}$. Krashchenko), when teaching the humanities (N. Marakhovska), in primary school students by means of outdoor games (A. Semenov), in extracurricular activities (N. Semchenko); educating leadership attitude of primary school students during extracurricular activities (O. Khmyzova), in person-centred educational process of comprehensive schools (V. Yahodnikova), etc.

At the same time, teacher's work is often characterised by a number of contradictions between: the society's needs for citizens with developed leadership qualities and the real state of teachers' preparedness for revealing and implementing students' leadership potential at all the stages of education at a comprehensive educational institution; for the formation of sports-oriented leadership qualities in middle school students by means of physical culture and absence of scientifically substantiated theoretical and methodological support of such training for future Physical Education (PE) teachers.

The aim of the paper is to consider the content of preparing future Physical Education teachers for the formation of middle school students' leadership qualities.

\section{Research methods}

The theoretical level of the research involved analysis and generalisation of the content of syllabi and curricula with the aim of identifying the problem state in the work of higher educational institutions, revealing the essence of preparing future PE teachers for the formation of sports-oriented leadership qualities; at the empirical level we used observation methods intended for determining the state of future PE teachers' preparedness for the 
formation of middle school students' sports-oriented leadership qualities.

\section{Discussion}

Determining the content of preparing students of for the formation of sports-oriented leadership qualities in middle school students, we relied on the fact that it should be based on the following pedagogical conditions: reflecting the ideas about the essence and mechanisms of leadership formation in the content of preparing future $\mathrm{PE}$ teachers; mastering the technique of pedagogical support of the formation of students' sports-oriented leadership qualities at PE classes; getting future PE teachers involved in situations requiring the formation of students' sports-oriented leadership qualities in team and playing sports.

The research was based on the fact that future PE teachers are prepared for organising team and playing sports at middle school when learning the subject "Theory and Methods of Teaching Athletic Games". A disciplinespecific standard of higher education in the field of study 6.010201 "Physical Education" for the discipline "Theory and Methods of Teaching Athletic Games" involves learning the following thematic modules: basketball as a subject; basketball technique; basketball tactics; methods of teaching and organising educational and training process; general concepts about physical training and methods of physical qualities development; organising and holding competitions; students' research on basketball issues; practical training. The content of these modules is represented in details in the following topics: basketball as a subject; history of basketball origin and development in the world and in Ukraine; safety rules for basketball classes; laws of the game and judging basketball competitions; technique training of a basketball player; methods of teaching and advancement of offense and defence tactics in basketball; general framework for teaching and advancement methods; methods, means and forms of educational process organisation; teacher's assessment at basketball classes; general and specific physical training of basketball players; methods of basketball players' general and specific endurance development; methods of basketball players' speed-power qualities development; methods of basketball players' agility, flexibility and coordination capabilities development; organisation and methods of conducting general physical education lessons; competition types and competing systems, their characteristics; working out competition regulations; analysis of laws of the game; students' research on basketball issues; making notes and conducting basketball lessons taking into account age and individual peculiarities of schoolchildren of different ages.

Thematic modules covering methods of teaching volleyball, handball and football at middle school were arranged in a similar way.

National standard for the compulsory subject "Theory and Methods of Teaching Athletic Games", which is a part of future PE teachers' professional training, demonstrates that the issues of forming leadership qualities in general and middle school students' sports-oriented leadership qualities in playing sports in particular are not covered by the content of the subject.

For this reason and according to the first pedagogical condition - reflecting the ideas about the essence and mechanisms of leadership formation in the content of preparing future PE teachers - the content of the subject programme (which included the modules "Theory and Methods of Teaching Basketball", "Theory and Methods of Teaching Volleyball", "Theory and Methods of Teaching Handball", and "Theory and Methods of Teaching Football") was supplemented with the following topics: leadership qualities and characteristic features of their manifestation; factors of forming sports-oriented leadership qualities; peculiarities of sports-oriented leadership qualities demonstration by middle school students in team and playing sports; forms and methods of forming sportsoriented leadership qualities in middle school students in athletic games.

The content of lectures included information about moral (responsibility, honesty, fairness), organisational (the ability to plan, see near-term prospect, form a team, lead the way, earn and keep great reputation), psychological (observation skills, empathy, tolerance, reflection, flexibility), and sporting (command of the game technique, training methodology, procedure of preparation for win) qualities of a sports team leader (apart from his/her personal qualities).

The students' attention was drawn to the fact that personality's position of a leader cannot be considered separately without a certain team. At the initial stage of team formation, student's personal attitude towards the goal of group's sporting work is of primary importance. In case of more mature team of students, the main factor affecting choice of a leader is his/her personality's meeting the norms and values of the group. In other words, at the beginning of group's functioning, every student can find his/her place and position in the system of relationship in it; with the development of a student group as a team, determination of its norms, it is up to the team to position every member of it. However, this process does not limit the role of every single personality and his/her activity, which contributes to the achieving of higher levels by the team.

Therefore, every PE teacher must know how leader's position of a student is formed; what leader's position can lead to in the process of work in a student group; how this position can affect students' personal states and relationships between them; the components of leadership status, etc.

We share the opinion of $\mathrm{H}$. Tazhutdinova that activities of a team mediate relationships between group members, are content-related characteristics of their communication, facilitate the revealing of personal qualities of each member. Developed business and moral qualities of a personality demonstrated in a certain activity are the basis for authority, which forms leader's status [1, p. 14]. 
If a person is popular and not authoritative in a group, he/she will not have significant impact on others, as long as his/her authority is minimised due to the lack of extensive communications with other people (because of asociality or for other reasons). Thus, authority is a content-related and popularity is a dynamic aspect of leadership.

One more factor that was taken into account when supplementing the content of the subject programme was critical analysis of the requirements to students' physical education. For example, the reason why PE classes at school did not contribute to the formation of sportsoriented leadership qualities was figured out. PE classes are mostly focused on the system of normative standards, which are to be reached. However, most students are short of time for adequate preparation, and teachers lack time for implementing innovative scientifically grounded teaching methods required for the formation of leadership qualities. In most cases, PE classes turn into forced motor activity and it becomes impossible to stimulate children's need in physical exercises. For this reason, there is an urgent need for critical assessment of the priorities at PE classes, for developing new criteria of effectiveness of physical training and physical culture in terms of forming sports-oriented leadership qualities and their place in the comprehensive system of student's personality development.

In general terms, the content of the subject programme included the following units:

1. Personality and its leadership qualities (general concepts about leaders, leadership, leadership qualities); contemporary scientific approaches to understanding the essence of factors of personality's leadership, leadership models. ties.

2. Components of sports-oriented leadership quali-

3. Social, psychological and pedagogical factors of forming sports-oriented leadership qualities, peculiarities of their demonstration by middle school students.

4. Teacher's supervision of the process of forming sports-oriented leadership qualities in middle school students.

These units involved detailed discussion of the following issues:

- scientific approaches to the development of leader's personality conception and differences between them;

- basic concepts about leadership among children;

- the system of criteria for middle school students' sports-oriented leadership qualities;

- methods of diagnostics, assessment and selfassessment of sports-oriented leadership qualities;

- social, psychological and pedagogical methods of children's motivation for leadership;

- factors affecting personality development in terms of leadership;

- psycho-pedagogical support of the formation of middle school students' sports-oriented leadership qualities;
- development of person-oriented programmes for the formation of middle school students' sports-oriented leadership qualities.

When discussing these issues with students, particular attention was paid to their culturological and professional orientation.

The culturological aspect of knowledge and abilities related to leadership and formation of sports-oriented leadership qualities is considered as methodological and general theoretical basis for professional development of a future specialist. This knowledge and culture-related abilities provide the formation of future teacher's professional values, development of the ability to make a conscious choice among various alternatives and areas of professional activities, formation of systemacity as an important quality of thinking.

The second aspect is students' understanding of the mechanisms of development, education and formation of certain personal qualities of a student. It is important to prepare a specialist who understands theoretical background of the educational process well and is able to predict its development, consequences of various influences.

The their aspect reflecting the content of the issues discussed related to students' knowledge of means of developing sports-oriented leadership qualities, techniques and methods of work on their formation in middle school students, the most appropriate forms of learning activity. Particular importance was attached to determining the limits of the most effective use of certain means of forming sports-oriented leadership qualities, their advantages and disadvantages.

The fourth aspect of systematisation of the content of the subject programme was based on students' knowledge of criteria and indicators of efficiency of teacher's work on the formation of sports-oriented leadership qualities, diagnostic techniques for the monitoring of these qualities development.

The fifth aspect is the ability to use theoretical knowledge for solving typical professional problems associated with the formation of middle school students' sports-oriented leadership qualities. For comprehensive preparation of a specialist for work in the sphere of physical education, it is important to teach him/her use this knowledge for solving professional problems.

Taking all of these aspects into account, the students' knowledge of the content of every topic was systemised in the following sections:

- information and cognitive section (what a teacher must know);

- activity section (what a teacher must be able to do);

- methodical section (how a teacher can organise the formation of middle school students' sports-oriented leadership qualities).

Below is the example of using these blocks to complement the content of the unit "Personality and its leadership qualities". 
1. Information and cognitive section, which includes theory related to chosen topics. According to this section, students should provide middle school students with the following information:

- who a leader is;

- groups of leadership qualities;

- what qualities a leader must possess;

- a leader and his/her role in class' life;

- a leader-facilitator, his/her capabilities and their development;

- a leader and his/her team;

- $\quad$ sports-oriented leadership qualities; oriented;

what qualities are considered to be sports-

- how sports-oriented leadership qualities are demonstrated.

2. Activity section including practical reproduction of theoretical knowledge of the chosen topics. As a result of learning this section, students must be able to teach schoolchildren:

- take on a role of a "big brother";

- be decisive, confident, reserved, persistent, organised, demanding;

- take responsibility for group members' actions;

- lead the group;

- develop the sense of success;

- build confidence.

3. Methodical section (teacher's aid). Developing didactic, role-playing games that facilitate the formation of students' knowledge, abilities and skills according to the content of this unit.

In order to implement the second pedagogical condition - mastering the technique of pedagogical support of the formation of students' sports-oriented leadership qualities at PE classes - interactive teaching forms were applied. When choosing methods and techniques of its implementation, we took into consideration the fact that the external factor of professional development is training and educational process, which involves acquisition of knowledge, abilities and skills as well as development of individual peculiarities, personal and leadership qualities of a future teacher, which enable him/her to master professional duties himself/herself and perform them in the most effective way.

The development of professional competence requires future teacher's understanding of what is supposed to happen, under what conditions, in what way and how he/she can make it happen. Bare knowledge is insufficient in this case. A future teacher must learn first-hand how to observe some processes associated with acquisition of sports-oriented leadership qualities and bringing them in his/her work, being distracted in the course of selfcognition.

Educational space involves the following forms of the educational process: special courses, training course modules, self-study, extracurricular classes, and tutorials. Active forms and methods of teaching are fundamental in this case (lectures-discussions, business games, specific situation analysis, trainings, etc.).

Currently, there are a number of ways and means of purposeful development of leadership qualities. Firstly, it is work with the regulatory sphere, secondly - with the cognitive one, and thirdly - doing certain exercises and creating the conditions that are necessary for person's professional activities. Mastering the technique of pedagogical support of the formation of sports-oriented leadership qualities in school students was implemented by means of various training and educational events, namely: problem-based and discussion-based lectures, business games, roleplaying games, trainings, etc.

Problem-based lectures. Problem-based approach differs from traditional approaches by the proportion and place of a problem-based situation in the structure of activity. Traditional methods provide students with certain knowledge at first, and after that they are offered training exercises for its consolidation. According to the problem-based approach, students initially face a certain problem, whose solving requires their independence. The principle of this kind of teaching is as follows: from a problem to knowledge, not from knowledge to a problem.

Problem-based lectures used in the educational process stimulated the development of creative thinking. In fact, solving a problem-based situation is usually a creative act, which results in acquiring certain knowledge and moreover positive emotional experience of success and a sense of satisfaction. A wish for experiencing these feelings causes emergence of new and development of existing cognitive motives, which are necessary for leadership competencies of a specialist.

The main difficulties of problem-based teaching are associated with the choice of problem-based tasks. The latter were chosen according to the following criteria: 1) they are interesting for learners; 2) they are easily understandable (based on the acquired knowledge); 3) they create a "zone of proximal development", i.e. they are manageable and not too trivial; 4) they give particular knowledge according to curricula and syllabi; 5) they develop profession-related thinking.

Discussion-based lectures. Some elements of discussion (controversy, collision of viewpoints, deliberate exasperation of contradictions in the material discussed) were used in organisational forms of teaching, including lectures. Two teachers were involved in lecturesdiscussions; they represented two opposite points of view of a problem. In some cases, students debated with each other. It is preferable that participants of a discussion represent certain groups, which activates sociopsychological mechanisms of forming value-orientation unity, group identification, etc., which in its turn intensifies or even generates new motives for a certain activity.

It is important that discussions are usually followed by afteractions in the form of cognitive activity stimulated by emotional impulse received during a discussion.

The subjects of discussion were subject-related, moral problems, interpersonal relations of group members. Results of these discussions (especially under condi- 
tions of moral choice) modify human behaviour much better that simple acquisition of some moral norms at the level of knowledge.

Business games. We used various types of business games for educational purposes and solving real problems (scientific, practical, organisational, etc.) - educational games, simulations, roleplaying, activity organising games, operational, managerial, innovative, etc.

A business game is a form of reproducing subjectrelated and social content of specialist's future work, simulation of the system of relations typical for this kind of activity as a whole (V. Baburin).

Such reproduction is possible due to sign means, models and roles played by other people. When a game is organised properly, a learner performs activity, which is professional in form, but educational in meaning and main results. It should be remembered that simulated educational model always simplifies real situation, especially by means of limiting its dynamism and elements of development. A learner usually deals with fragments of different stages of situation development.

Effectiveness of educational business games in terms of forming leadership qualities compared to more traditional forms of teaching (e.g. lectures) is possible due to fuller reproduction of real conditions of professional activities as well as due to more comprehensive personal involvement of a student in a game situation, intensification of interpersonal communication, vivid emotional experience of success or failure. As distinct from discussion-based and training methods, there is an opportunity for purposeful providing of a student with effective means of solving problems in the form of a game, which reproduce the context of significant elements of professional activity, including leadership.

Two-aspect nature of game methods, i.e. combination of game and educational aspects makes it possible to approach game conditions to real conditions of professional activities. Domination of game conditions over the real ones leads to the fact that players can get too excited and ignore the educational aspect of a business game. Domination of real conditions over the game ones results in reduction of motivation and loss of all advantages of this method.

Both discussion-based methods and trainings are focused on problematicity elements. The tasks are supposed to include certain contradictions that a learner should deal with (V. Andreiev).

Trainings. Choosing trainings in our work we relied on the following facts:

- a training is one of the most available means of intensive teaching, which is achieved by means of strong emotional refreshment and intensive feedback, whose mechanisms motivate participants for more appropriate and deep self-analysis and self-consciousness, facilitates the processes of identification and reflection;

- a training enables a student to lean to think and act independently under favourable conditions, when consequences of a mistake made are insignificant; it also enables participants to exteriorise the experience gained, subject it to reflection, criticism and development;

- a training makes it possible to intensify changes, use every participant's capabilities to the full; it stimulates analytical activity, provides participants with tools and techniques of analysis and demonstrates advantages of such an approach;

- trainings can be used at different stages of knowledge formation during professional development of a specialist.

The third pedagogical condition - getting future PE teachers involved in situations requiring the formation of students' sports-oriented leadership qualities in team and playing sports - presupposed systematisation of knowledge acquired by students during the second stage of the experiment and development of firm activity stereotypes related to the formation of middle school students' sports-oriented leadership qualities in team and playing sports. For this purpose, athletic games classes involved exercising organisation of middle school students' activities aimed at the formation of sports-oriented leadership qualities in team games. Besides, the points of discussion were as follows: peculiarities of professional training and teacher's attitude to a situation; comprehension of the gap between theoretical knowledge and results of one's own work related to positioning a leader in a group of school students (in particular, when dealing with a certain pedagogical situation); emotional experiences reflection, desire to overcome this gap; understanding the point of the contradiction by means of giving common examples of teacher's work intended for determining the position of a leader and turning the conversation to the peculiarities of solving this problem; self-regulation by means of creating a plan for self-improvement in terms of forming students' sports-oriented leadership qualities; summarising self-analysis concerning the prediction of ways and means of teacher's work in terms of forming students' sports-oriented leadership qualities.

Analysis of experience in solving the problems created in these situations enable future teachers to acquire a number of ideas how to solve them, guidance that helps act quickly and effectively using safe and proven method during the changing process of pedagogical communication - interaction with school students.

\section{Conclusions}

Results of the experimental data analysis at the final stage of the experiment confirmed the effectiveness of the proposed pedagogical conditions, which have been implemented in the process of preparing future PE teachers for forming middle school students' sports-oriented leadership qualities.

Further research works are expected to be devoted to revealing the methods of preparing future PE teachers for forming sports-oriented leadership qualities in middle school students. 


\section{REFERENCES}

1. Tazhutdinova, G. Sh. (2001). Vzaimosviaz liderstva i napravlennosti lichnosti podrostka [Interaction between leadership and adolescent's personality orienta-

\section{ЛІТЕРАТУРА}

2. Тажутдинова Г. Ш. Взаимосвязь лидерства и направленности личности подростка : автореф. дис. на соискание уч. степени канд. психол. на- tion]. Extended abstract of candidate's thesis. Moscow [in Russian].

ук : спец. 19.00.07 «Педагогическая психология» / Г. Ш. Тажутдинова. - Москва, 2001. - 21 с.

Вікторія Володимирівна Нестеренко, доктор педагогічних наук, професор кафедри дошкільної педагогіки, Південноукраӥнський національний педагогічний університет імені К. Д. Уиинського, вул. Нішинського, 1, м. Одеса, Украӥна, Ганна Вімаліївна Тімова, кандидат педагогічних наук, старший викладач кафедри спортивних ігор, Південноукраӥнський національний педагогічний університет імені К. Д. Уиинського, вул. Фонтанська дорога, 4, м. Одеса, Украӥна

\section{ЗМІСТ ПІДГОТОВКИ МАЙБУТНІХ УЧИТЕЛІВ ФІЗИЧНОЇ КУЛЬТУРИ ДО ФОРМУВАННЯ СПОРТИВНИХ ЛІДЕРСЬКИХ ЯКОСТЕЙ В УЧНІВ ОСНОВНОӤ ШКОЛИ}

У статті подано зміст підготовки майбутніх учителів фізичної культури до формування спортивних лідерських якостей в учнів основної школи відповідно до педагогічних умов, а саме: відображення у змісті підготовки майбутніх учителів фізичної культури уявлень про сутність і механізми формування лідерства; оволодіння методикою педагогічної підтримки й супроводу формування спортивних лідерських якостей учнів на заняттях із фізичної культури; занурення майбутніх учителів фізичної культури в ситуації, що вимагають формування спортивних лідерських якостей учнів у командно-ігрових видах спортивної діяльності. Відповідно до першої педагогічної умови було доповнено зміст робочих програм навчальної дисципліни «Теорія і методика викладання спортивних ігор», такими темами: лідерські якості й ознаки їх прояву; чинники формування спортивних лідерських якостей; особливості прояву спортивних лідерських якостей в учнів основної школи в командноігрових видах спортивної діяльності та ін. Оволодіння методикою педагогічної підтримки і супроводу формування спортивних лідерських якостей учнів (друга педагогічна умова) здійснювалося через навчально-виховні заходи, а саме: проблемні лекції, дискусійні лекції, ділові ігри, рольові ігри, тренінги та ін. Третя педагогічна умова передбачала систематизацію знань, накопичених студентами в процесі другого етапу експерименту і вироблення в них стійких стереотипів діяльності щодо формування спортивних лідерських якостей в учнів основної школи в командно-ігрових видах спортивної діяльності. 3 цією метою на практичних заняттях зі спортивних ігор відпрацьовувалися прийоми організації діяльності учнів основної школи в командних іграх, спрямованих на формування спортивних лідерських якостей. Результати аналізу експериментальних даних підтвердили ефективність окреслених педагогічних умов, які були реалізовані у змісті підготовки майбутніх учителів фізичної культури до формування спортивних лідерських якостей в учнів основної школи.

Ключові слова: підготовка, майбутні учителі фізичної культури, педагогічні умови, спортивні лідерські якості, учні основної школи.

Submitted on April, 18, 2017 